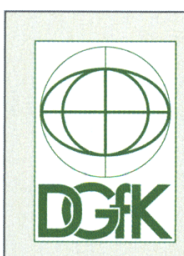

KN Kartographische Nachrichten Journal of Cartography and Geographic Information 67. Jahrgang, April 2017, Heft 2 Herausgeber: Deutsche Gesellschaft für Kartographie e.V. (DGfK) - Gesellschaft für Kartographie und Geomatik, vertrete durch den Präsidenten Prof. Dr. Manfred Weisensee

Organ der Deutschen Gesellschaft für Kartographie e.V. (DGfK), der Schweizerischen Gesellschaft für Kartografie (SGK) und der Österreichischen Kartographischen Kommission (ÖKK) in der Österreichischen Gesellschaft für Geographie (ÖGG).

Schriftleitung

Hauptschriftleiter

Prof. Dr. rer. nat. habil. Mark Vetter (zuständig für Aufsätze Berichte). Hochschule Karlsruhe - Technik und Wirtschaft, Moltkestr. 30, 76133 Karlsruhe; redaktion@kartographischenachrichten.de, Fon: 0049(0) 7219252599

Weitere Schriftleiter

Prof. Dr. phil. Frank Dickmann (Zweiter Schriftleiter, zuständig für Nachrichten aus Hochschulen und Institutionen, Rezensionen). Ruhr-Universität Bochum, Geographisches Institut,

Postfach, 44780 Bochum; frank.dickmann@rub.de

Fon: 0049(0) 234 32-23379; Fax: 0049(0) 234 32-14964

Dipl.-Ing. Andreas Gollenstede (zuständig für Geoinformation

aktuell) Haareneschstr. 91, 26121 Oldenburg; kn@gollenstede.com Fon: 0049(0) 441 7779-545; Fax: 0049(0) $4417779-750$

Dr.-Ing. Thomas Chudy (zuständig für DGfK-, SKG- und ÖGGNachrichten). Martin-Luther-Universität Halle-Wittenberg, Institut für Agrar- und Ernährungswissenschaften, Karl-Freiherr-von-

Fritsch-Straße 4, 06120 Halle/Saale, Fon: 0049(0) 3455522448 ;

Fax: 0049(0) 3455527109

Prof. Dr. Reinhard Zölitz (zuständig für Nachrichten aus Hoch-

schulen und Institutionen), Institut für Geographie und Geologie,

Kartographie und GIS, Friedrich-Ludwig-Jahn-Str. 16,

D-17489 Greifswald, Fon 03834864523 , Fax: 03834864501

E-Mail:zoelitz@uni-greifswald.de

Mitarbeit für die Schweiz: Prof. Dr. Lorenz Hurni. Institut für

Kartografie, ETH Hönggerberg, 8093 Zürich; hurni@karto.baug.ethz

ch. Fon: 0041 16333033; Fax: 00411631153

Mitarbeit für Österreich: Univ.-Prof. Dr. Wolfgang Kainz

Institut für Geographie und Regionalforschung, Universität Wien,

Universitätsstraße 7/5, 1010 Wien; wolfgang.kainz@univie.ac.at

Fon: 0043 14277-8640; Fax: 0043 14277-9531

Ehrenschriftleiter

Prof. i. R. Dr. Jürgen Dodt, Witten

Dr. rer. nat. h. c. Rolf Harbeck, Bonn

Editorial Board

Prof. Dr. H. Asche, Potsdam; Prof. Dr. Manfred Buchroithner,

Dresden; Prof. Dr. Dirk Burghardt, Dresden; Prof. i. R. Dr. Jürgen

Dodt, Witten; Prof. Dr. D. Dransch, Potsdam; Prof. Dr. M. Ehlers,

Osnabrück, Berlin; Prof. Dr. S. I. Fabrikant, Zürich, Schweiz:

Ass.-Prof. Dr. S. Fuhrmann, Fairfax, USA; Prof. Dr. G. Gartner, Wien,

Österreich: Prof. Dr. D. Grünreich, Ronnenberg: Dr. Rolf Harbeck,

Bonn; Prof. Dr. A. Hüttermann, Ludwigsburg; Prof. Dr. L. Hurni,

Zürich; Prof. Dr. W. Kainz, Wien; Prof. Dr. P. Kammerer, München:

Prof. Dr. W. G. Koch, Dresden; Prof. Dr. Menno-Jan Kraak, Twente

Netherlands; Prof. Dr. Jukka Krisp, Augsburg; Prof. Dr.-Ing.

L. Meng, München; Prof. Dr. J. Schiewe, Hamburg; PD Dr.-Ing.

J. Schoppmeyer, Bonn; Prof. Dr. J. Schweikart, Berlin; Prof.

Dr.-Ing. M. Sester, Hannover; Prof. Dr.J. Siemer, Regina, Kanada;

Prof. Dr. R. Zölitz, Greifswald

Manuskripte richten Sie bitte an den zuständigen Schriftleiter.

Hinweise zur Gestaltung des Manuskripts finden Sie unter

www.kartographische-nachrichten.de > Autorenhinweise.

Reviewverfahren

Wissenschaftliche Beiträge werden im Rahmen eines Peer-ReviewVerfahrens begutachtet. Trotz sorgfältiger Redigierung übernehmen Herausgeber, Redaktion und Verlag keine Haftung für die inhaltliche Richtigkeit der Veröffentlichungen.

Die KN Kartographische Nachrichten ist in der internationalen Zitationsdatenbank Scopus gelistet.

Die DGfK ist Mitglied der

Internationalen Kartographischen

Vereinigung IKVIICA.

Verlag: Kirschbaum Verlag $\mathrm{GmbH}$, Siegfriedstraße 28,

D-53179 Bonn / Postfach 210209, D-53157 Bonn,

Fon: (0228) 95453-0, Fax: (0228) 95453-27;

Internet: http://www.kirschbaum.de, E-Mail: info@kirschbaum.de

Anzeigenleiter: Volker Rutkowski; zurzeit ist Anzeigenpreisliste

Nr. 52 vom 1.10 .2016 gültig

Bezugspreise und ISSN: Inland/Ausland Jahresabonnemen

inkl. E-Paper und elektronischem Archiv 74,- Euro zzgl.

Versand 9,80,- Euro (jeweils einschl. MwSt.)

Einzelheft 18,- Euro zzgl. Versand

Die Zeitschrift erscheint alle zwei Monate. ISSN 0022-9164

Kündigungsfrist 6 Wochen zum Auslaufen des Abonnement-

Kündigungs
Zeitraumes

Satz: EMS Eckert Medienservice, 53359 Rheinbach

Druck: johnen-druck GmbH \& Co. KG, Industriegebiet Bornwiese,

54470 Bernkastel-Kues

\section{Current Approaches of User Studies in Cartography}

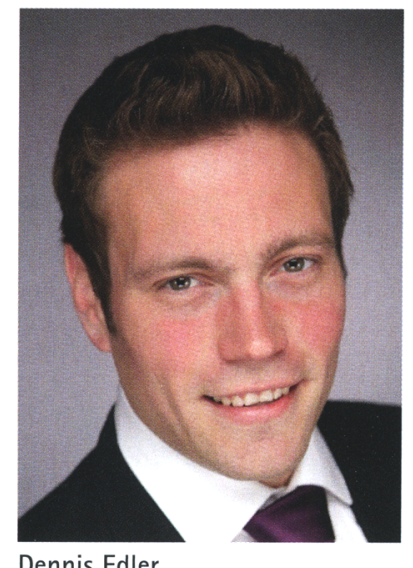

Dennis Edler
The technical developments in and around cartography have become enormous. Many examples exist where cartographers left the traditional field of 2D graphics. Instead, they have become visualizers of 3D models and animations, GIS and database experts, managers of big data adopted from social media, sound engineers or designers of virtual realities (VR) - just to mention a few examples showing the potential but also the high demands of our discipline. Within the rapidly growing world of fashionable visualization techniques inviting us to explore and expand map-making, we must not forget the addressee of our cartographic products: the map user!

Having a closer look at the papers recently published in the international journals of cartography, it becomes obvious that many international research teams are currently paying attention to answering fundamental questions of cartographic visualization by conducting user studies. These studies are based on modern methods, and their relevance for cartography exists without any doubts: How do people read animated or specifically coloured maps, and how can modern eye-tracking devices and new quantifying metrics help to identify differences between specific user groups? How should map symbols be designed to improve spatial orientation, and how can established experimental methods of experimental psychology be applied to develop study designs? Do sound effects or specific 3D designs in interactive cartographic visualizations improve map-reading performance?

These questions, and many others not mentioned here, back up what has been stated and tried to be taken out into the world by numerous international researchers and research teams since Arthur H. Robinson's pioneering work The Look of Maps: An Examination of Cartographic Design (1952): Our discipline requires empirical user testing to clarify how maps should be constructed and designed to meet the present and future demands of users in different everyday application scenarios. To support this idea together with international colleagues, this KN special issue has been planned for almost a year. The final compilation includes five research articles focussed on modern methods and applications currently considered by the international cartographic research community.

Alžběta Brychtová and Arzu Çöltekin evaluate established and recommended sequential colour schemes in terms of colour distance, a reliable metric to investigate whether two colours can be perceptually distinguished by map users. Findings of a lab study are also reported by Anne-Kathrin Bestgen and colleagues, who conducted an eye-tracking experiment focused on the impact of map grids on distance estimates and the corresponding viewing behaviour. Florian Hruby gives another view on the Peters projection controversy and derives some new research question for empirical cartography. Based on an online survey, Sebastian Meier addresses the perceived credibility of cartographic visualizations in online journalism. Finally, Alenka Poplin shows that user studies concerning emotions felt at a specific place within a city can provide new input for urban planning and thematic cartography.

Enjoy reading, best wishes - and herzliche Grüße!

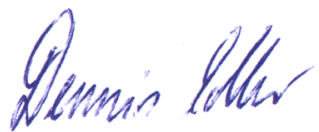

Dennis Edler 